\title{
Heavy Metals Accumulation of Different Parts of Turbinaria spp. along the Olaikuda Coast, Rameshwaram, Tamilnadu, India
}

\author{
Suparna Roy ${ }^{1}$, P. Anantharaman ${ }^{2}$ \\ Centre of Advanced Study in Marine Biology, Faculty of Marine Sciences, Annamalai University, Parangepettai, \\ Tamilnadu, India ${ }^{1,2}$
}

\begin{abstract}
Heavy metals pollution is a leading problem in aquatic environment. Many expensive techniques have been applied to treat seawater for removal of heavy metals. Heavy metals remediation by seaweeds is less cost-effective and eco-friendly method. The main aim of the present study is to evaluate the trace metals accumulation by different parts (Foliage like part, Stem like part and reproductive part) of two species of Turbinaria such as Turbinaria decurrens and Turbinaria ornata collected from Olaikuda, southeast coast of India. This is the first time study to estimate of heavy metals content of different parts Turbinaria decurrens and Turbinaria ornata to find the specific area which is mainly responsible for accumulation of high amount of heavy metals. ICP-MS (Inductively Coupled Plasma Mass Spectrometry) was used to estimate the trace metals content. This work reveals that the foliage part (leave like structure) and reproductive part of both species are accumulating highest amount of $\mathrm{Pb}, \mathrm{Cd}, \mathrm{As}, \mathrm{Fe}$ and $\mathrm{Cr}$. Turbinaria spp. are not edible for its quite hard and thorny morphological structure, but as they are accumulating heavy metals in high amount expectedly, both species will be utilized for removal of heavy metals from polluted area as bioremediator. From this study, it is concluded that both of the Turbinaria sp. will be used as bio-indicator of heavy metals pollution in the marine environment.
\end{abstract}

Keywords: Turbinaria sp., Different parts, Heavy metals, Remediation.

\section{INTRODUCTION}

Anthropogenic activities on land, in marine environment and air are contributing toxic contaminants to the seawater, sediments and marine organism. Marine macroalgae are distributed globally along the coast, islands and the marine environment, easily identify and collectable and have high content of heavy metals, so marine macroalgae are used as indicator of trace metals pollution in the marine environment [1]. Previous literatures[6,2] revealed that at least 53 elements are present in seaweeds, of which some elements such as Calcium, Magnesium, Sodium, Potassium, Sulphur and Phosphorous are present in high amounts and directly or indirectly have been used for cellular building blocks. Several researchers worked on the elementals composition of seaweeds of Pamban Bridge, southeast coast of India such as the elementals composition of Sargassum longifolium and Turbinaria conoides [4]. Heavy metals accumulation in some seaweed including Turbinaria spp. and some sea grass at Kanyakumari, southeast coast of India were investigated by [5]. But the Olaikuda coast till is now not explored by any other researcher before, though this area of coast is continuously affected by anthropogenic activities and the land contaminants. Many studies have been conducted on the trace metals remediation by different marine plants to find the suitable one, as some of seaweeds are edible in different parts of the World and the research is in progress to find out the more number of edible seaweeds, so trace metals composition and accumulation capacity of seaweeds is really significant to identify the toxic composition of seaweeds as above the threshold level trace metals are toxic to environment as well as human. As trace metals are non biodegradable, so it circulates within different trophic levels of food chain causing human health problems [3]. The trace metals are magnified after entering into different higher animals (biomagnifications) causing toxicity to their body. It causes physical distress above its threshold level which developed different health problems in humans.

Seaweeds are excellent fodder of fishes and the marine fishes are consumed by people in different parts of the World. Specifically, the leave like soft parts of seaweeds are consumed by fishes, so heavy metals content of different parts of seaweeds will specify the possibility of toxicity of heavy metals in specific fishes. Seaweeds life cycle and reproductive cycles are quite complicated. Some seaweeds are perennial, living for many years while some are annuals. Seaweeds reproduction may occur sexually by joining specialized male and female reproductive cells called gametes. Sporophyte produce spore which settle and grow into male and female plants called gametophyte. This gametophyte produce gametes called sperm or egg which fertilized and produce zygote which developed sporophyte. In Turbinaria spp. sexual and asexual both types of reproduction occur. 


\section{International Advanced Research Journal in Science, Engineering and Technology \\ ISO 3297:2007 Certified}

Vol. 4, Issue 3, March 2017

\section{MATERIALS \& METHODS}

pilgrim centre in the Gulf of Mannar, Tamilnadu, India. It is connected to the mainland by Pamban Bridge. Olaikuda

\section{a. Study area:}

beach $\left(09^{\circ} 18.853^{\prime} \mathrm{N} 079^{\circ} 20.141^{\prime} \mathrm{E}\right)$ is one kilometre away

The area of Rameshwaram is 51.8 sq. Kms. $\left(09^{\circ} 18.390^{\prime \prime} \mathrm{N}\right.$ from the principal shrine of Rameshwaram. It is 079 20.076' E) which is located $570 \mathrm{kms}$ from the State surrounded by seaweeds and coral reefs. Seaweeds are Capital, Chennai. Rameshwaram, a small island and major abundantly growing in this area.

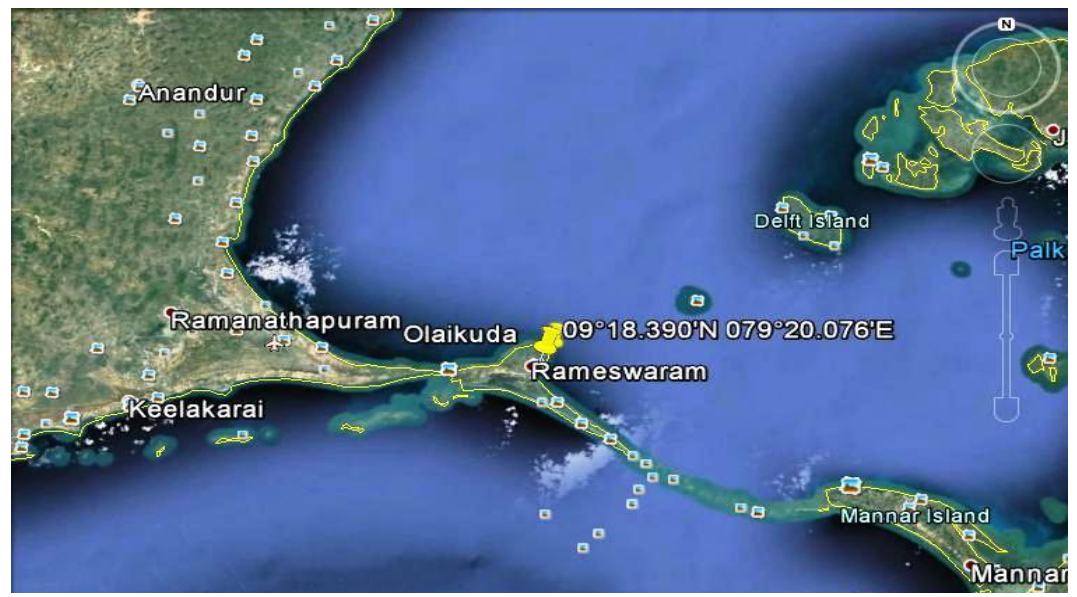

Figure: Map showed the area of collection.

\section{b. Studied species:}

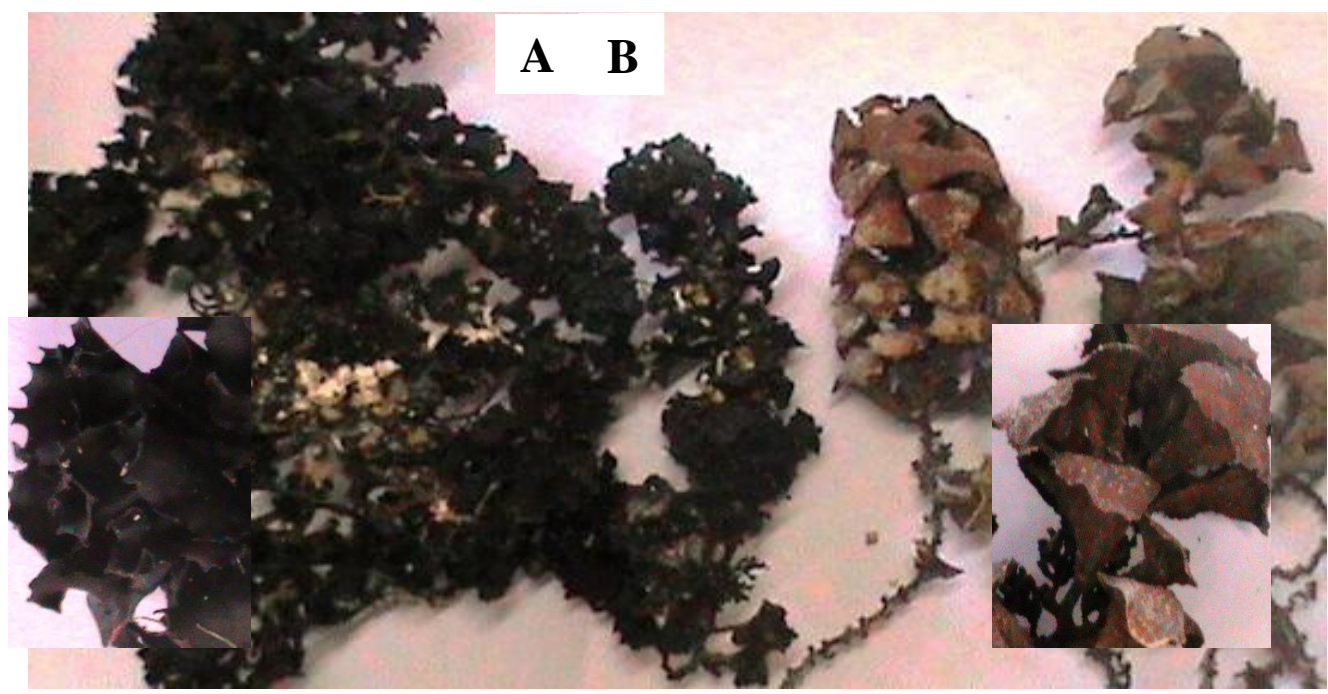

A. Turbinaria ornata [TO] (Turner). J. Agardh; Turbinaria decurrens [TD] Bory de Saint Vincent.

c. Method: Accurately, 1 gm dry seaweed powder had been taken in the conical flask and $20 \mathrm{ml}$ concentrated $\mathrm{HNO}_{3}$ was added to it . The mixtures were kept at room temperature $\left(28-34^{\circ} \mathrm{C}\right)$ for $28 \mathrm{hrs}$. Then samples were boiled at $120^{\circ} \mathrm{C}$ hotplates and evaporated to dryness. The dry samples in the conical flask were left at room temperature for 18 hours; then added $20 \mathrm{ml}$ of Nitric acid and Perchloric acid (4:1) to each sample, acidified samples were again boiled and evaporated to dryness at $120^{\circ} \mathrm{C}$ hotplates. The samples were cool for few hours and the 20 ml $10 \%$ concentrated $\mathrm{HNO}_{3}$ were added to it and filtered the samples with What man (589/2) filter paper covering
B. cotton and the filtrates were collected in a $250 \mathrm{ml}$ clean conical flasks and diluted accurately to $25 \mathrm{ml}$ volume with double deionised water and the samples were analysed with Inductively Coupled Plasma Mass Spectrometry (ICP-MS) Agilent ICP-MS 7700 Series.

d. Statistical Analysis: The triplicates of samples were used to find out the mean and the standard deviation of Turbinaria spp.

\section{RESULTS AND DISCUSSIONS}

The accumulation of heavy metals by seaweeds occurs by different possible mechanisms such as adsorption, intracellular compartmentalization of metals, chelation, 
Vol. 4, Issue 3, March 2017

secretion of extracellular exudate etc. The resistance and the reproductive part which includes sporophyte, including tolerance to high level of heavy metals in gamete and in this work three different parts are separately polluted marine environment by seaweeds occur through treated for their heavy metals contents specifically for the above mentioned mechanism. Though, some internal toxic As, Pd, Cd and Cr, So we can specify the particular factors are also responsible to support the resistance to area of highest accumulation of trace metals. So, we may trace metals and the rate of accumulation of heavy metals add mechanism of metals accumulation by morphological such as the cell wall composition, the quantity and the and anatomical structures. Our study revealed that in case types of polysaccharides present in that area because the of Turbinaria deccurens the reproductive part is rate of affinity of binding of polysaccharides to the metals accumulating highest amount of $\mathrm{Pb}-1.47 \pm 0.16 \mathrm{ppb}, \mathrm{Cd}-$ increase the accumulation rate as well as the $23.47 \pm 1.3 \mathrm{ppb}, \mathrm{Fe}-2226.28 \pm 1.09 \mathrm{ppb}$ and $\mathrm{Cr} 5.71 \pm 0.07$ Metallothionein protein present in that particular marine ppb but stem like part accumulated high $\mathrm{Cd}$ as $6.89 \pm 0.20$ seaweeds species. The accumulation of metals by $\mathrm{ppb}$, in case of Turbinaria ornata, foliage part accumulated seaweeds also depends on life cycle duration of the highest As $442.33 \pm 0.60 \mathrm{ppb}$, the foliage part contains $\mathrm{Pb}$ particular species, the seasonal variations, and the growing $2.21 \pm 0.02 \mathrm{ppb}$ and Fe $4420.29 \pm 1.12 \mathrm{ppb}$. Chromium is environment pollution level. Seaweeds are not like higher high in both species reproductive parts but not detected in plants but they have thallus structure including root like other parts of thallus.

structure (hold fast), leave like part (stripe), stem like part

Table: Heavy metals content of Turbinaria spp.

\begin{tabular}{|l|l|c|l|l|l|l|}
\hline $\begin{array}{l}\text { Serial } \\
\text { No. }\end{array}$ & $\begin{array}{l}\text { Different parts of } \\
\text { Turbinaria spp. }\end{array}$ & \multicolumn{1}{|c|}{$\mathrm{Pb}(\mathrm{ppb})$} & \multicolumn{1}{|c|}{$\mathrm{Cd}(\mathrm{ppb})$} & \multicolumn{1}{|c|}{ As $(\mathrm{ppb})$} & \multicolumn{1}{|c|}{$\mathrm{Fe}(\mathrm{ppb})$} & $\mathrm{Cr}(\mathrm{ppb})$ \\
\hline 1. & TD Stem like part & $0.85 \pm 0.01$ & $\mathbf{6 . 8 9} \pm \mathbf{0 . 2 0}$ & $120.90 \pm 0.77$ & $851.12 \pm 1.05$ & 0 \\
\hline 2. & TO Stem like part & $0.003 \pm 0.00$ & $0.76 \pm 0.01$ & $\mathbf{2 4 2 . 3 5} \pm \mathbf{0 . 7 3}$ & 0 & 0 \\
\hline 3. & TD Foliage part & $0.69 \pm 0.012$ & $5.65 \pm 0.16$ & $11.79 \pm 0.35$ & $702.21 \pm 1.08$ & 0 \\
\hline 4. & TO Foliage part & $\mathbf{2 . 2 1} \pm \mathbf{0 . 0 2}$ & $11.79 \pm 0.33$ & $\mathbf{4 4 2 . 3 3} \pm \mathbf{0 . 6 0}$ & $\mathbf{4 4 2 0 . 2 9} \pm \mathbf{1 . 1 2}$ & 0 \\
\hline 5. & TD Reproductive & $\mathbf{1 . 4 7} \pm \mathbf{0 . 1 6}$ & $\mathbf{2 3 . 4 7} \pm \mathbf{1 . 3}$ & $99.53 \pm 0.47$ & $\mathbf{2 2 2 6 . 2 8} \pm \mathbf{1 . 0 9}$ & $\mathbf{5 . 7 1} \pm \mathbf{0 . 0 7}$ \\
\hline 6. & TO Reproductive & $\mathbf{1 . 9 2} \pm \mathbf{0 . 2 1}$ & $3.07 \pm 0.12$ & $129.37 \pm 1.13$ & $1229.13 \pm 0.70$ & $\mathbf{2 . 0 4} \pm \mathbf{0 . 2 6}$ \\
\hline
\end{tabular}
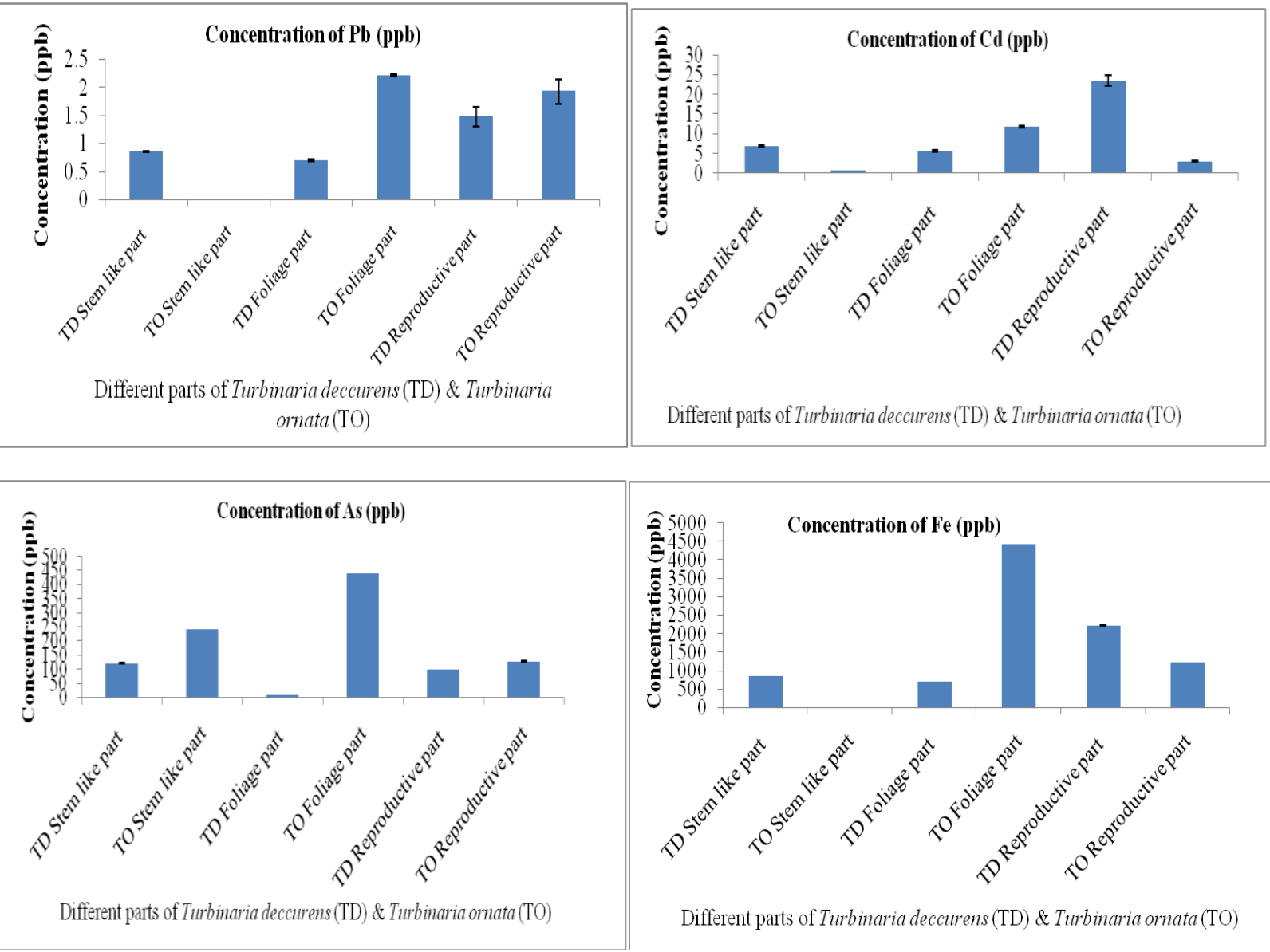


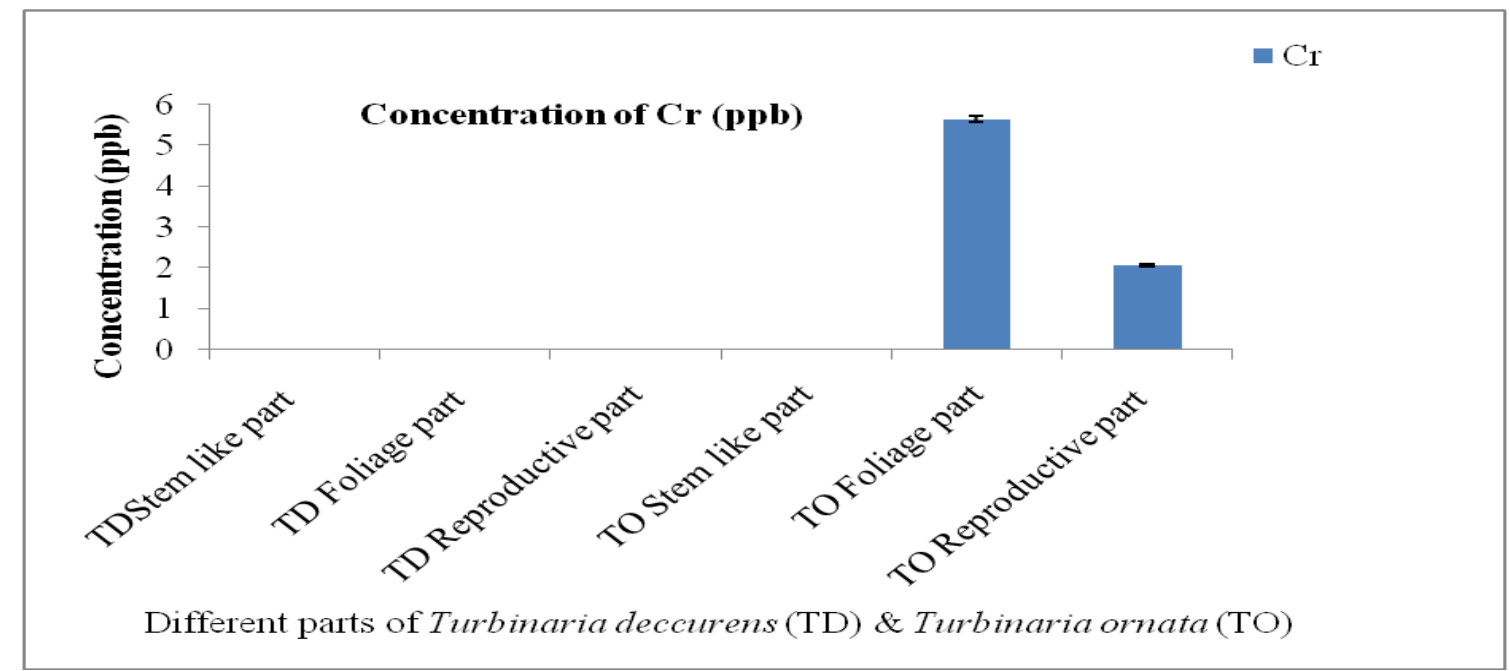

Figure: Graphs represent the heavy metals content of different parts of Turbinaria spp. (TD-Turbinaria deccurens \& TO-Turbinaria ornata).

The high accumulation of metals in leave like parts may be due to the broad surface area of foliage i.e. leave like parts and the compartmentalization of metals may occur in different parts of thallus depending on surface are or it may due to the distribution of different quantity of metals binding polysaccharides or the protein such as Metallothionein in different parts of thallus. The accumulation of heavy metals in different structural part of the thallus will include another theory of explanation of trace metals accumulation after extensive studies on heavy metals composition in different species of seaweeds.

\section{CONCLUSION}

The study of other species of brown, red and green seaweeds separately on the basis of the mentioned four parts will make the profile of accumulation of heavy metals on the basis of foliage part (leave like part), stem like part and the reproductive part. For future research, it will include another explanation of accumulation of heavy metal on the basis of different morphological and anatomical structure.

\section{ACKNOWLEDGEMENT}

The authors are thankful to Dr. B. Shanthi and Dr. K. Siva Kumar of the Centralised Instrumentation and Service laboratory (CISL) at Department of Physics, Annamalai University for providing the ICP-MS instrumental facilities and analysis of samples and Our sincere thanks to the Dean and Director, Centre of Advanced Study in Marine Biology, Faculty of Marine Sciences, Annamalai University for proving the facilities to carry out this work successfully.

\section{REFERENCES}

11] Campanella, L., Conti, M. E., Cubadda, F., Sucapane, C. Trace metals in sea grass, algae and molluscs. From an uncontaminated area in the Mediterranean. Environ. Pollut. 111, 117-126, 2001.
[2] De Boer, J. A. Nutrients. In: C.S. Lobban and M. J. Wynne (Eds.). The Biology of Seaweeds, Blackwell Scientific Publication Oxford. 356-391p, 1981.

[3] He., M. Wang., Z. and Tang, H., The chemical, toxicological and ecological studies in assessing the heavy metals pollution in LE AN River, China. Wat. Res. Vol. 32: No. 2, pp- 510 -518, 1998,.

[4] Murugaiyan, K., and Narasimman, S. Elemental composition of Sargassum longifolium and Turbinaria conoides from Pamban coast, Tamilnadu. International Journal of Research in Biological Sciences, 2(4): 137-140, 2012

[5] Sudharsan, S., Seedevi, P., Ramasamy, P., Subhapradha, N., Vairamani, S., and Shanmugam, A. Heavy metals accumulation in Seaweeds and Sea grasses along the southeast coast of India. Journal of Chemical and Pharmaceutical research, 2012, 4 (9): 4240-4244.

[6] Vinogradov, A. P. The elementary chemical composition of marine organisms. Sears Foundation of Marine Research. Memoir, No. 2, Yale University 1953. 